\title{
Pentingnya Membangun Platform Kolaborasi Multi-Stakeholder sebagai Key Enabling Factor dalam Membangun Ekosistem Inovasi Industri 4.0 di Era New Normal
}

\author{
Satrio Utomo ${ }^{1}$, Agus Nugroho Harjono ${ }^{2}$ \\ Pusat Pengkajian Industri Manufaktur, Telematika dan Elektronika - BPPT \\ e-mail: ${ }^{1}$ satrioutomo2030@gmail.com, ${ }^{2}$ agusnh@gmail.com \\ Submitted Date: December $08^{\text {th }}, 2020$ \\ Revised Date: January $13^{\text {th }}, 2021$ \\ Reviewed Date: December $31^{\text {th }}, 2020$ \\ Accepted Date: June $14^{\text {th }}, 2021$
}

\begin{abstract}
Industry 4.0 is an era of technological disruption or industrial revolution 4.0 because it puts more emphasis on system automation and connectivity which will make the mobility of the industrial world movement and job competition non-linear. The use of digital technology is one of the keys. Industry opportunities for industrial development 4.0 are an effort to increase industrial competitiveness, but many industries do not yet understand the concept and how to start the stages. One of the ways proposed as a policy in preparing industry 4.0 should be taken a multi-stakeholder collaborative approach to facilitate development, including gathering digital transformation initiatives so that limited resources can be optimal. As a form of soft industry policy, a platform organization is also needed as a sustainable program manager and provides technical facilities. From a technical point of view, it is necessary to prepare enabling technology that can be utilized by all actors in the cross-sectoral digital economy in an affordable manner. The Ecosystem Platform becomes a medium to be able to build synergy and collaborative across industries with all stakeholders in an effort to accelerate the transformation of industry 4.0 according to the national priority program of Making Indonesia 4.0. In line with that, coordination was carried out between parties in the industrial transformation 4.0 process, as well as building networks to develop positive cooperation, including government, academics or R\&D, industry players / associations, technical providers, consultants and of course financial actors in accelerating the industrial transformation process 4.0.
\end{abstract}

Keywords: industrie 4.0; platform; kolaboratif; multi stakeholder

\begin{abstract}
Abstrak
Industri 4.0 merupakan era disrupsi teknologi atau revolusi industri 4.0 karena lebih menekankan pada otomatisasi sistem dan konektivitas yang akan membuat mobilitas pergerakan dunia industri dan persaingan dalam dunia kerja menjadi tidak linear. Pemanfaatan teknologi digital menjadi salah satu kuncinya. Industri mengenali peluang perkembangan industri 4.0 sebagai salah satu upaya percepatan untuk meningkatkan daya saing industri, namun banyak industri belum memahami konsep dan bagaimana memulai tahapannya. Salah satu cara yang disarankan sebagai kebijakan dalam penyiapan industri 4.0 adalah perlu diambil pendekatan kolaboratif multi-stakeholder untuk memfasilitasi pengembangan, termasuk menghimpun inisiatif transformasi digital lain agar terbatasnya sumber daya bisa optimal. Sebagai bentuk soft industrial policy juga diperlukan pembentukan organisasi platform sebagai pengelola program yang berkelanjutan dan memberi fasilitasi teknis. dari sisi teknis perlu disiapkan enabling technology yang bisa dimanfaatkan semua pelaku digital ekonomi lintas sektoral secara terjangkau. Platform Ekosistem menjadi media untuk dapat membangun sinergi serta kolaboratif lintas industri dengan seluruh stakeholder dalam upaya mempercepat transformasi industri 4.0 sesuai program prioritas nasional Making Indonesia 4.0. Sejalan dengan itu, dilakukan koordinasi antar pihak dalam proses tansformasi industri 4.0, serta membangun jejaring untuk mengembangkan kerjasama yang positif baik pemerintah, akademisi atau R\&D, pelaku / asosiasi industri, technical provider, konsultan dan tentunya financial actor dalam akselerasi proses transformasi industri 4.0.
\end{abstract}


Kata kunci: industrie 4.0; platform; kolaboratif; multi stakeholder

\section{Pendahuluan}

Secara general, industry 4.0 merupakan istilah revolusi industry ke-4 dimana proses industri manufaktur sepenuhnya didukung oleh teknologi digital terintegrasi, saling berhubungan / berkomunikasi satu dengan lain dan dioptimasikan dengan Artificial intelligence/kecerdasan buatan, internet of things, otomatisasi robotic, big data serta machine learning. Sebagai negara dengan pertumbuhan ekonomi terbesar di Eropa dan terbesar keempat di dunia, Jerman melihat industri 4.0 sebagai peluang menempatkan posisinya dalam industry manufaktur global. Jerman menamakan sebagai Industrie 4.0 dimana Jerman menggabungkan dunia digital dengan dunia produksi manufaktur. (Veile \& Kiel, 2019)
Industrie 4.0 juga mengintegrasikan rantai suplai dari berbagai sumber termasuk negara lain yang menjadi partner dagang Jerman. Oleh karena itu, pada tahun 2018 Jerman telah membuat progress dalam apa yang mereka sebut Driving (International) Standardisation. Dalam mengintegrasikan seluruh system, harus ada common language yang menghubungkan seluruh system. Working group (WG) dibentuk untuk mengembangkan pedoman untuk standard I40. Mengacu pada platform industry 4.0 Jerman, di dalam struktur litbangjirap (specialist expertise) dibentuk beberapa kelompok kerja (Working Group) memiliki peran dan tugas masing-masing. (Kagermann H, Wahlster W, \& Helbig J, 2013)

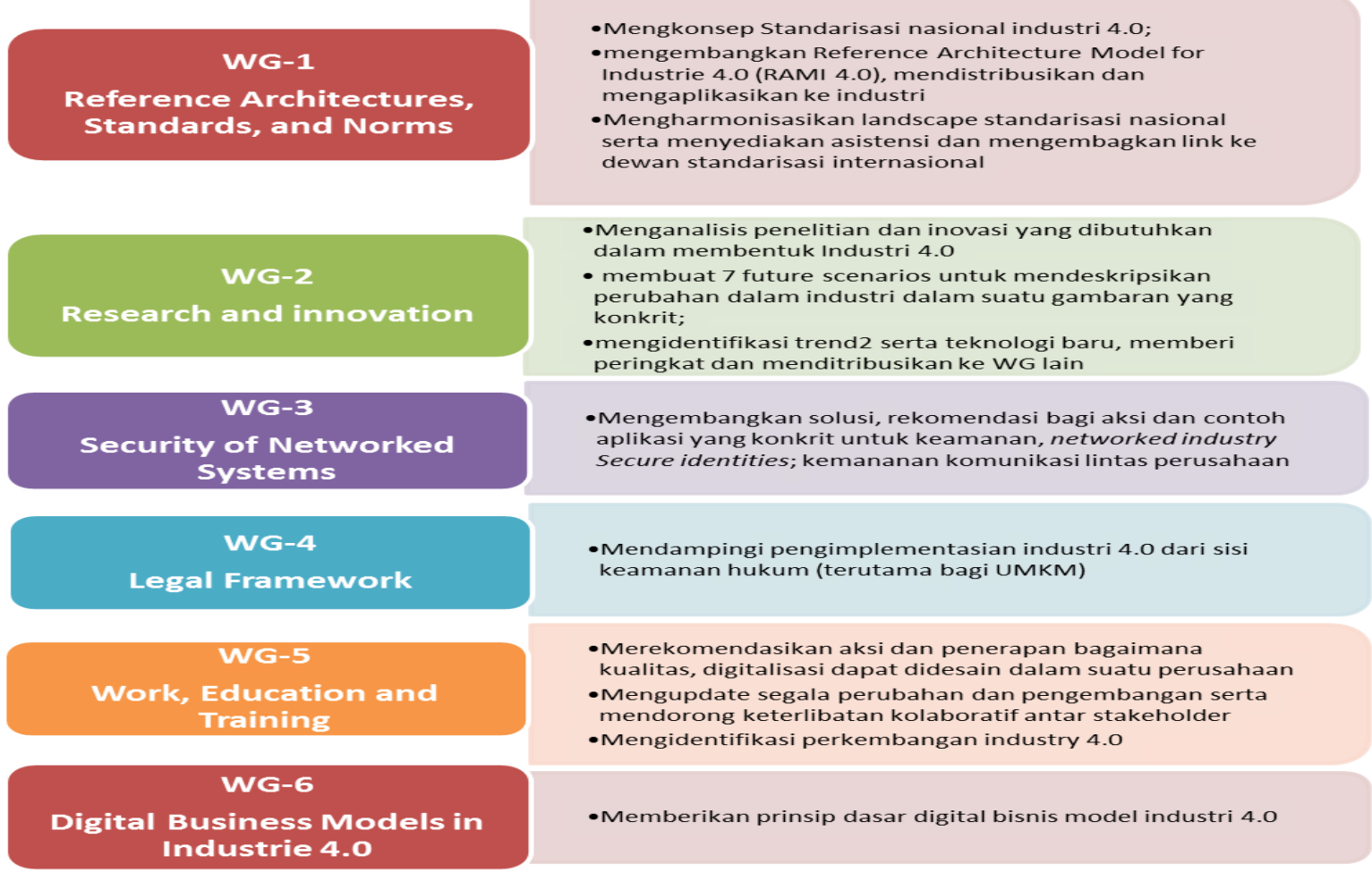

Gambar 1. Model Framework industrie 4.0

Mengingat rantai suplai / Supply Chain tidak hanya berasal industri dalam negeri saja, Negara Jerman menjalin kerjasama dalam rangka standardisasi dengan berbagai negara. Hal ini dimaksudkan agar produk, komponen, dan proses dalam terkoneksi via teknologi infomasi dan komunikasi. Sehingga rangkaian ini dapat saling berkomunikasi secara virtual. Platfom Industrie
4.0 menyusun pola References Architecture Model for Industrie (RAMI) 4.0 dengan referensi model dari negara - negara lain. Amerika, Jepang, China, Italy dan Perancis merupakan negara yang telah menjalin kerjasama dalam proses standardisasi ini. (Veile \& Kiel, 2019)

Benchmarking pada negara Jerman yang menjadi pioneer dalam implementasi industry 4.0, 
dimana pemerintah Jerman membuat platform industry 4.0 yang bukan saja bersifat nasional tetapi telah menjadi referensi atau dasar bagi pengembangan industry 4.0 dunia, yang memposisikannya sebagai "central network in Germany to advance digital transformation towards Industrie 4.0." Platform industri 4.0 Jerman memiliki tugas menyusun rekomendasi dan memberi masukan bagi penentu kebijakan dalam menerapkan industri 4.0, mendukung penciptaan pengetahuan dan standar, memobilisasi bisnis dan UKM, mempromosikan jaringan global dan memastikan pelaksanaan Industri 4.0 di perusahaan Jerman (www.plattform-i40.de). (Kohler \& Weisz, 2016)

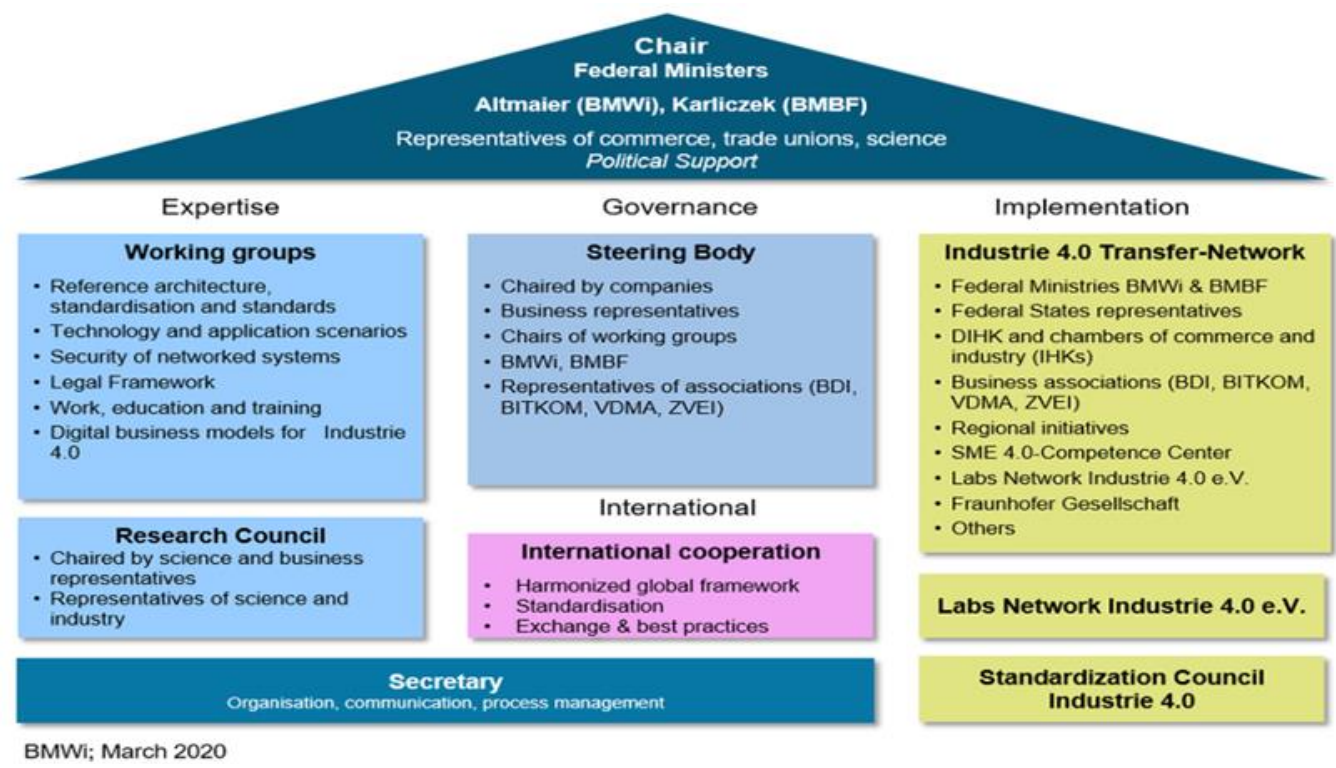

Gambar 2. Referensi Struktur Platform Kolaborasi (Industrie 4.0) Sumber: BMWi, 2018.

Belum adanya framework yang menjadi acuan bersama dan memayungi pengembangan Industri 4.0 secara holistik dan terpadu mengakibatkan masing-masing stakeholder menjalankan sistem atau komponennya sendirisendiri. saat ini banyak industri dalam negeri yang masih kesulitan untuk mencari acuan implementasi pengembangan Industri 4.0. Hal ini disebabkan fungsi kolaborasi dan koordinasi pemangku kepentingan masih belum dirasakan oleh industri, sehingga menyulitkan industri dan institusi berinvestasi dalam pengembangan industry 4.0, maka perlu dirumuskan mekanisme kolaborasi dan koordinasi. Di sisi lain, Indonesia punya peluang besar, yaitu termasuk 6 besar negara penghasil lulusan STEM (Science, Technology, Engineering and Mathematics) mengalahkan Jepang. Disini peran SDM sangat penting, terutama bidang rekayasa sistem dan integrasi sistem (Faisal \& Syam, 2020)

Sementara itu, banyak potensi dalam negeri yang relevan dan bahkan memiliki kemampuan kunci (seperti system engineering / development) yang dibutuhkan dalam ekosistem Industri 4.0 namun merasa perannya belum diberdayakan secara maksimum. Begitu juga dengan komunitas akademis yang sangat bersemangat berkontribusi namun belum menemukan wadah untuk menyamakan visi nasional untuk mewujudkan ekosistem besar sebagai dasar pengembangan pasar yang berkelanjutan. Juga beberapa sektor industri "bukan prioritas" (seperti sektor energi, fintech 4.0, smart city, goverment 4.0, dll) yang antus ingin melakukan transformasi digital. (Irianto D, 2017).

Hal yang tidak jauh berbeda juga dihadapi bahkan oleh institusi pemerintahan sendiri. Ketiadaan wadah bersama menghalangi dibangunnya solusi komprehensif. Hal ini mengakibatkan belum terintegrasinya berbagai program di berbagai instansi/kementerian yang meski ada namun berjalan sendiri-sendiri buah dari inisiatif masing-masing. Contoh Kominfo lebih memilih topik IoT, Kemenperin fokus 'hanya' pada industri sektor manufaktur, BPPT mendalami pengembangan teknologi AI, dll. Hal ini lebih lanjut mempersulit instansi pendukung lainnya yang tidak kalah penting perannya untuk 
berperan aktif membantu dalam membentuk ekosistem, seperti Kemenaker yang harus menyiapkan program pelatihan tenaga terampil, Kementrian hukum dan teknis yang menyiapkan framework hukum dan regulasi rincinya, dll.

Kondisi demikian akibat belum adanya pendekatan sistematis untuk mengintegrasikan peran serta berbagai stakeholder kunci. Langkah ini diperlukan untuk menghadapi tantangan multidemensional yang butuh banyak kompetensi dan mendapatkan sinergi dari unsur ekosistem yang hanya bisa diperoleh melalui kesamaan visi.

Tantangan utama dari penyusunan kebijakan pemerintah adalah untuk memastikannya efektif, policies that work dengan menghindari perubahan melalui intervensi langsung yang mengganggu keseimbangan pasar. Kebijakan yang diharapkan oleh Industri 4.0 adalah agar bisa membantunya membuka potensi besar dari pemanfaatannya bagi penciptaan lapangan kerja, pengurangan kemiskinan yang berujung pada peningkatan kualitas hidup.

Untuk itu harus disiapkan rancangan organisasi platform (yang mengatur struktur organisasi, fungsi, mekanisme, aktor, peran, dll) untuk memfasilitasi stakeholder dalam ekosistem agar dapat saling-terhubung, berkomunikasi, berinovasi, berbagi, dan saling-percaya untuk mendorong inovasi namun tetap menghargai nilai penting lain (privasi, paten, hak intelektual, dll.).

\section{Metode}

Adapun tahapan yang akan dilakukan adalah melakukan literature review dengan cara mengumpulkan beragam referensi, terutama yang terkait dengan kata kunci industrie 4.0, industry 4.0, technology industri, industri manufaktur dan hal-hal yang terkait dengan kondisi industri nasional di masa pandemic ini.

Referensi yang ada dipelajari, dipahami dan digunakan untuk menyusun kerangka (Framework) ekosistem Industri 4.0 yang mendukung kebutuhan industri dalam negeri sesuai dengan karakteristik dalam era revolusi Industri 4.0. Harapannya rancangan organisasi platform dapat menjadi wadah kolaborasi multistakeholder bagi transformasi digital guna membangun ekosistem Industri 4.0 yang terbaik digunakan dan sesuai dengan karakterisik dan kebutuhan Industri di Indonesia

\section{Pembahasan}

Saat ini Indonesia masih berada di peringkat 64 dari 103 negara dan berada pada nilai rata rata di ASEAN dalam kesiapan mengadopsi teknologi industri 4.0. Kesiapan adopsi diperlihatkan dari keberadaan infrastruktur dasar dan inovasi terkait teknologi (diantaranya penetrasi ponsel, penetrasi internet, belanja R\& D, publikasi, dan pendanaan venture capital). Penerapan industri 4.0 bisa menjadi satu terobosan langkah cepat sekaligus strategis untuk bisa membangkitkan aktivitas industri sektor manufaktur dalam negeri, khususnya pada tahap menghadapi dan menyesuaikan pada kebiasaan baru dalam kondisi pandemi Covid-19 saat ini. (Hadi \& Murti, 2019)

Seperti yang telah dilakukan oleh beberapa negara lain, seperti India dengan Make in India, Thailand dengan Thailand 4.0, Malaysia dengan Malaysia 4, Singapore dengan Singapore: Smart City, Smart Nation, maka Indonesia perlu menyusun rencana strategis dan mengidentifikasi pihak-pihak terkait untuk mempersiapkan industri dalam negeri dalam menerapkan Industri 4.0. Platform teknologi yang tepat berperan penting untuk mencapai tujuan yang ditetapkan. Indonesia membuat program nasional yaitu Making Indonesia 4.0 agar dapat mengejar ketertinggalan implementasi revolusi industri 4.0 dengan cara menyusun rencana strategis dan mengidentifikasi pihak-pihak terkait untuk mempersiapkan industri dalam negeri dalam menerapkan Industri 4.0. Platform teknologi yang tepat mampu berperan penting untuk mencapai tujuan yang ditetapkan. Dengan mendorong penerapan teknologi 4.0 ini membuat proses industri tetap terjaga sesuai prosedur dengan tata kelola yang baik.

Salah satu upaya pemerintah dalam menumbuhkan kembali industri nasional (reindustrialisasi), pada tahun 2018 Pemerintah telah menyiapkan strategi implementasi industri $4.0 \mathrm{di}$ Indonesia. Kementerian Perindustrian sebagai leading ministry merancang program Making Indonesia 4.0 sebagai Road map (peta jalan) terintegrasi guna menerapkan strategi yang menjadi prioritas nasional dalam upaya memasuki industri 4.0. (Kemenperin, 2020). Dibutuhkan peran kolaboratif antar stake holder terkait baik pemerintah, akademisi atau R\&D, pelaku / asosiasi industri, technical provider, konsultan dan tentunya financial actor dalam akselerasi proses transformasi industri 4.0 .

Pemerintah Indonesia telah menetapkan 10 agenda prioritas nasional antara lain :

1. Memperkuat alur aliran material (strengthen supply chain); dengan cara meningkatkan supply bahan baku dasar dalam negeri sehingga dapat mengurangi import bahan baku, 
membangun industri manufaktur komponen yang bernilai tinggi, contoh industri komponen elektronik.

2. Mendesain ulang zona industri (Industrial zone development); dengan cara membangun zona industri baru sejalan dengan sektor prioritas making Indonesia 4.0 sekaligus membangun konektivitas diantara zona industri. Pertimbangan geografis, infrastruktur, transportasi serta aspek yang lainnya sehingga akan lebih komprehensif

3. Akomodasi standar sustainability (Sustainable development goal); dengan cara mengidentifikasi peluang pertumbuhan serta promosi investasi lingkungan kondusif yang ramah lingkungan contoh mendorong penggunaan bio plastic, membangun kemampuan industri nasional berbasis teknologi bersih (kendaraan beremisi karbon redah), mengembangkan kendaran bertenaga biofuel dan gas, mengembangkan kendaran EV (Electric Vehicle) berbasis tenaga listrik berikut komponennya.

4. Memberdayakan UMKM (Usaha mikro, kecil dan menengah); dengan cara membangun platform e-commerce secara nasional, mengembangkan sentra berbasis teknologi dalam upaya peningkatan akses UMKM terhadap perubahan akuisisi teknologi dan memberikan support mentoring untuk mendorong inovasi .

5. Membangun infrastruktur digital untuk kepentingan nasional; dengan cara mempercepat pembangunan broadband speed dan kemampuan digital, menyelaraskan standar digital dengan norma dunia, peningkatan kerjasama antara pemerintah, public dan swasta agar berinvestasi pada teknologi digital seperti data center, cloud, infrastruktur broadband serta security management.

6. Menarik investasi asing; dengan cara bekerja sama dengan industri manufaktur global serta menawarkan insentif yang menarik, serta membuka komunikasi dialog bisnis dengan pemerintah asing agar dapat berkolaborasi tingkat nasional. Hal tersebut dapat mendorong transfer teknologi ke industri lokal.

7. Peningkatan kualitas SDM; dengan cara mengubah kurikulum dengan adopsi pendidikan STEAM (Science, Technology, Art, Engineering and Mathematics), serta peningkatan kurikulum sekolah kejuruan, Untuk sementara memanfaatkan bakat asing agar bisa transfer pengetahuan baru kepada
SDM lokal karena masih kekurangan ketersediaan kebutuhan tenaga kerja ahli dalam industri 4.0.

8. Pembentukan ekosistem inovasi; pemerintah menyusun blue print pusat inovasi nasional / litbang, mempersipkan percontohan atau pilot project pusat inovasi untuk Research and Development and Design (R\&D\&D) serta optimalisasi regulasi terkait, termasuk kegiatan diantaranya adalah perlindungan HAKI dan intensif fiscal untuk percepatan kolaboratif antar lintas sektor antara pemerintah dan industri serta akademis / universitas

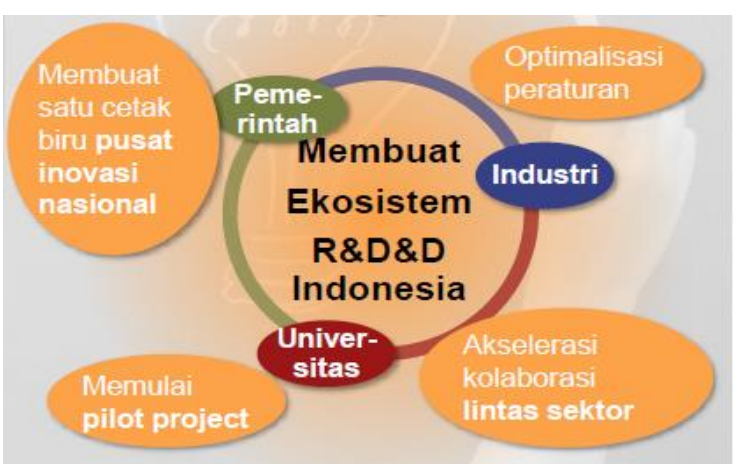

Gambar 3. Skema ekosistem inovasi

9. Menerapkan program insentif dan investasi teknologi untuk berbagai industri; dengan cara memberikan insentif, subsidi dan dukungan pendanaan. untuk insentif pajak berupa berupa tax holiday, pengurangan atau penghapusan bea pajak import untuk industri yang mengadopsi teknologi industri 4.0. Untuk subsidi dalam bentuk dukungan serta hibah perangkat teknologi kepada industri pilihan yang mengadopsi teknologi industri 4.0 (khususnya robotika dan new energy vehicles). Untuk dukungan pendanaan berupa jaminan modal atau penambahan modal atau bagi kegiatan investasi dan inovasi dalam bidang teknologi mutakhir.

10. Harmonisasi aturan dan kebijakan industri untuk mendukung tingkat daya saing serta memastikan adanya koordinasi stake holder yang erat antara kementerian dan lembaga teknis (seperti kementerian perdagangan, kementerian perindustrian, kementerian ESDM, kementerian keuangan) terkait penyusun kebijakan dengan pemerintah daerah.

Roadmap industri 4.0 pada tahap awal difokuskan kepada lima (5) sektor industri 
strategis nasional yang telah mampu mendorong sekaligus signifikan berkontribusi pertumbuhan ekonomi nasional berdasar pada tingkat PDB (Product Domestic Bruto) manufaktur (57\%), ekspor industri manufaktur (64\%), serta jumlah penyerapan pekerja industri (59\%) mencakup:

1. Industri makanan dan minuman; menjadi industri yang terdepan dan terkuat di ASEAN khususnya Food and Beverage Powerhouse.

2. Industri otomotif; menjadi pusat industri yang memproduksi untuk kebutuhan pasar domestic dan juga eksport untuk kendaraan bermotor khususnya Electrified Vihacle (EV) dan internal combustion engine (ICE).

3. Industri elektronik; menjadi industri yang siap memenuhi kebutuhan pasar domestic dan ekspor dengan cara mengembangkan kemampuan pelaku industri domestik, contoh kebutuhan komponen elektronika.

4. Industri kimia ; untuk menjadi industri yang terdepan sektor bio kimia yang siap memenuhi kebutuhan pasar domestic maupun ekspor.

5. Industri tekstil dan produk tekstil; untuk menjadi industri khususnya produksi pakaian fungsional, contohnya baju olahraga.

Pola pendekatan kolaboratif multistakeholder dan sinergitas antara pemerintah dan industri serta akademis / universitas perlu dilakukan sebagai bentuk dukungan bersama dalam upaya mewujudkan ekosistem inovasi dengan memfasilitasi pengembangan, termasuk menghimpun inisiatif transformasi digital lain agar terbatasnya sumberdaya bisa optimal. Sebagai bentuk soft industrial policy juga diperlukan pembentukan organisasi platform sebagai pengelola program yang berkelanjutan dan memberi fasilitasi teknis. Platform ini menjalankan fungsi esensial dari ekosistem agar Industri 4.0 bisa mulai tumbuh secara sistematik, hingga terbangunnya ekosistem Industri 4.0 sebenarnya secara penuh. Selain itu dari sisi teknis perlu disiapkan enabling technology yang bisa dimanfaatkan semua pelaku digital ekonomi lintas sektoral secara terjangkau.

Implementasi industri 4.0 diharapkan akan dapat membawa peluang besar dan tentunya positif dalam memperbarui kemampuan manufaktur Indonesia, yaitu dengan meningkatkan produktivitas terhadap biaya dan juga membangun kemampuan inovasi lokal industry dalam negeri.

Untuk itu perlu dikembangkan skema platform kolaborasi dalam ekosistem industri 4.0 untuk mengakomodir para pihak dalam proses transformasi industri 4.0. Skema ini bisa menjadi bentuk wadah untuk membangun ekosistem industri 4.0. Pada prinsipnya ekosistem inovasi industri 4.0 perlu segera diwujudkembangkan sebagai proses akselerasi transformasi industri 4.0

Teknologi menjadi satu langkah untuk menekan dampak pandemi ini. Industri yang enggan bertransformasi dan mengutilisasi teknologi tidak hanya akan tertinggal, namun berpotensi kehilangan market share. Perlu inovasi dan teknologi menjadi sebuah investasi penting bagi industri untuk bisa bertahan dan berkompetisi. Implementasi industri 4.0 merupakan pilihan strategi tepat membangkitkan aktivitas industry sektor manufaktur untuk dapat berdaya saing pada fase new normal ini, karena efisiensi dan produktivitas sehingga sangat berpotensi untuk membuka atau menciptakan pasar baru. Dengan menggunakan teknologi big data, maka prediksi kebutuhan dan arah pasar dapat lebih akurat. (Jay, Bagheri, \& Kao, 2013)

Selain itu perlu dipikirkan kebijakan pendidikan dan penyiapan tenaga kerja perlu terus dievaluasi untuk menyikapi kebutuhan akan SDM yang pro aktif dan relevan dengan kebutuhan pasar yang dengan cepat bisa berubah. (Yuliati \& Suhandi, 2019)

Ternyata, tidak di duga, awal tahun 2020 terjadi krisis global melanda di seluruh dunia termasuk negara Indonesia yang terkena dampak akibat ada pandemic virus COVID-19. Sampai saat ini krisis global khususnya dampak terhadap pada aktivitas industry ini belum tahu kapan berakhir. Sektor Industri manufaktur, yang menyumbangkan lebih dari 20\% PDB (Produk Domestik Bruto) Nasional, sangat mempengaruhi pertumbuhan ekonomi nasional 2020 karena menurunnya permintaan atas produk barang atau jasa dari pasar domestic dan pasar global.

Pandemi Covid-19, memberi masukan bagi Kemenperin untuk menambahkan dua industry potensial, yaitu industri farmasi dan industry alat kesehatan. Sehingga sekarang menjadi 7 (tujuh) sector industry prioritas dalam roadmap industri 4.0. Kedua sector industri tersebut mampu berkinerja positif baik serta mengalami permintaan produk yang cukup tinggi saat masa pandemi. (Kemenperin, 2020). 
Penyebaran virus Corona yang belum berhenti ini menjadikan titik acuan ada kebutuhan nasional agar akses internet dan teknologi dapat lebih merata ke seluruh penjuru Indonesia. Industri di Indonesia harus mempersiapkan diri menghadapi disruption atau perubahan besar dan persaingan baru di era industri 4.0 ini. Diperlukan kerja keras dan upaya yang tidak mudah dari pihak-pihak terkait agar industri dalam negeri mampu bertahan saat ini. Perlu semangat kreatifitas agar industry dapat memanfaatkan peluang agar dapat bertahan dan terus bisa berkembang, salah satunya optimalisasi digitalisasi dan inovasi produk serta kolaboratif dengan pelaku pasar untuk perluasan pasar ekspor.

Banyak ulasan terkait dampak negatif akibat pandemi, namun pada sisi lain ada nilai positif, yaitu memberi dampak untuk akselerasi adaptasi Revolusi Industri 4.0, dimana industri seperti diharuskan dapat menyesuaikan adaptasi pada fase kenormalan baru. Pandemi Covid-19 membuat industri berusaha untuk mengadopsi, melibatkan dan dapat bertransformasi digital dalam kehidupan sehari-hari.

Bahwa Covid-19 dapat menjadi momentum industri nasional untuk segera bisa mengadopsi. Kegiatan bisnis serta operasional sepenuhnya akan bergantung konektivitas jaringan dan sistem. Pertukaran data dan informasi dalam produksi serta operasi dilakukan cepat sebagai upaya penciptaan produk dan jasa. Sistem kerja yang sebelumnya masih konvensional atau semi berubah menjadi otomatis dibarengi dengan penyesuaian mekanisme supervisi.

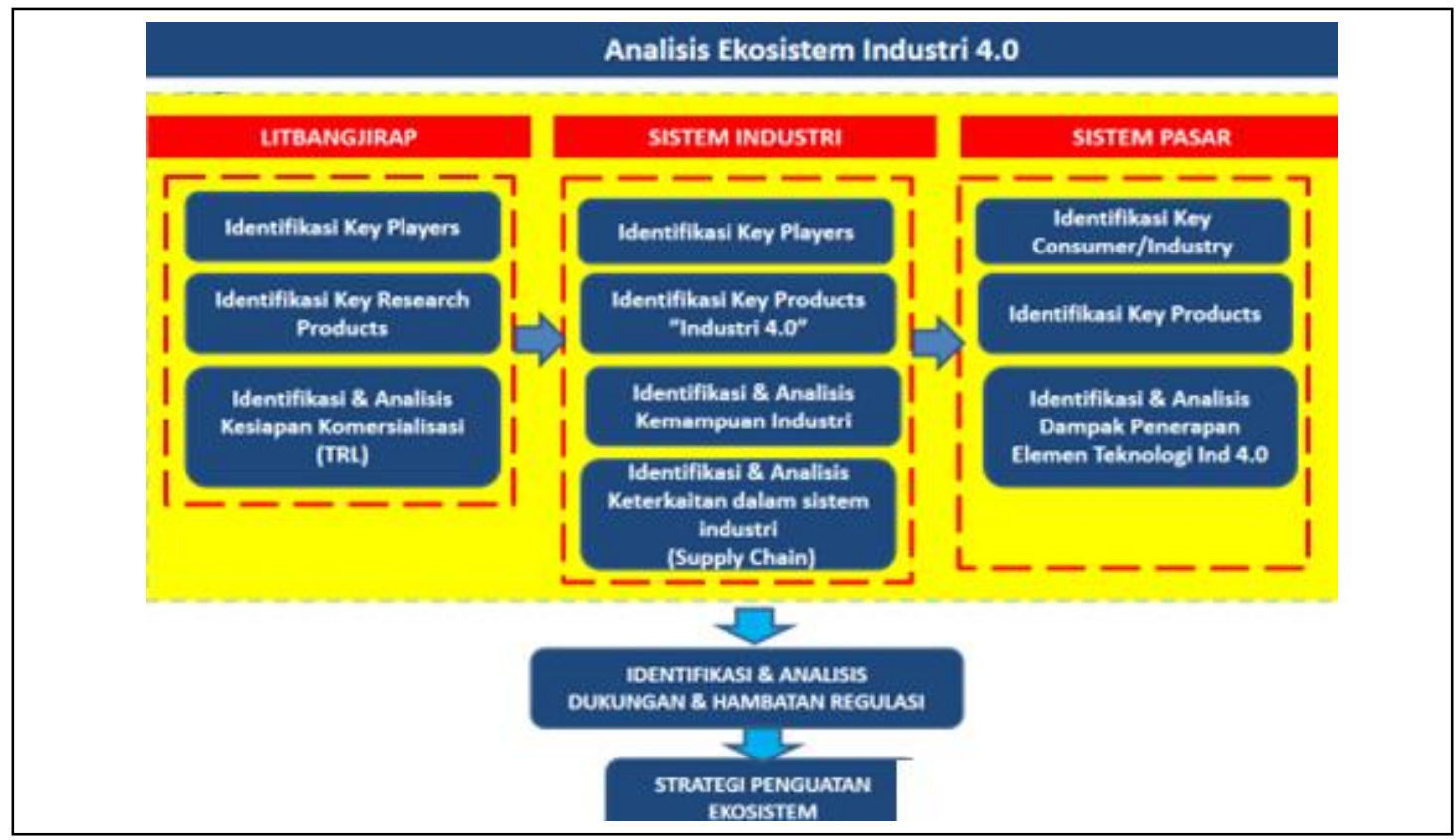

Gambar 4. Pemetaan actor dalam ekosistem industri 4.0

Model platform kolaborasi multi stakeholder dalam membangun ekosistem industry 4.0 ini melibatkan berbagai instansi: litbangjirap, system industry, dan juga system pasar. Mulai dari mengidentifikasi actor-aktor utama yang terlibat dari masing-masing system yang terlibat: institusi pemerintah, asosiasi industri, pelaku usaha, penyedia teknologi, juga lembaga riset dan pendidikan. Selanjutnya, mengidentifikasi produk penelitian kunci dan juga produk-produk industry utama yang dimasukkan dalam kategori pengembangan industry 4.0.

Untuk dapat membangun Ekosistem inovasi Industri 4.0 dengan konsep pentahelix, dimana pemerintah, perguruan tinggi, industri, komunitas, dan media bersama-sama berperan sesuai keahlian dan bidangnya. Dengan demikian terwujudnya open innovation yang akan mengikatkan antara penelitian dengan industri. (Utomo, Susalit, Setiastuti, \& Hakim, 2020)

Berikut stakeholder (ABG\&C: Akademis Bussiness Government and Community) yang dapat dilibatkan dalam membangun ekosistem industri 4.0 ideal dan sesuai karakteristik dan kebutuhan industri di Indonesia saat ini diantaranya adalah :

a. Kemenperin - sebagai leading ministry Industri 4.0

b. KemenRistek / Badan Riset Inovasi Nasional (BRIN) - sebagai bagian dari kesiapan 
transfer riset dan teknologi nasional

c. Kemenaker - untuk pengembangan training industri, Kominfo, Universitas, dll

d. Kemenaker - sebagai mitra regulasi, pengembang dan fasilitator training industri dan pendidikan vokasi SDM agar berkompeten dan berdaya saing

e. Kominfo - sebagai mitra fasilitator dan regulasi teknis ICT sebagai sektor penting pendukung Industri 4.0

f. Kemendiknas - sebagai mitra dalam regulasi pengembangan kurikulum dan saranaprasaraana pendidikan dalam rangka penyiapan SDM

g. Kementerian Keuangan (BKF) - sebagai mitra regulasi insentif fiscal dan non-fiscal

h. Industri (sebagai sponsor industri elektronika berbasis teknologi digital seperti PT. TSM, PT. Xirka Silicon Technology, dll)

i. Otoritas Jasa Keuangan (OJK) - sebagai mitra regulasi untuk industri financial technology (fintech).

j. Asosiasi pendukung Industri 4.0 (Asioti, Mastel, ACCI, ABDI, IAIS dll)

k. Perguruan Tinggi - sebagai mitra R\&D industri (ITS, ITB, Binus, UMN, Telkom University, dll).

1. Lembaga intermediasi (incubator \& akselerator) baik berasal dari pemerintah, perguruan tinggi maupun industri (Balai Inkubator Teknologi / BIT, Bandung TechnoPark / BTP, Binus Incubator, Sky Ventura, XL camp, dll)

m. Lembaga keuangan perbankan dan nonperbankan sebagai mitra investasi bagi industri

BPPT merupakan salah satu lembaga litbangjirap nasional, yang turut berkontribusi mempersiapkan era Industri 4.0 melalui program pengembangan riset di bidang Artificial Intelligent: (Lab AI, TMC-AI, e-TWS-AI), Big Data serta Data Security. BPPT juga telah memulai pondasi industri 4.0 dengan meresmikan strategi nasional kecerdasan artifisial 2020-2045 yang membawa indonesia sejajar dengan negara lain dalam adaptasi kecerdasan artificial dengan memaksimalkan SDM bertalenta, sumber daya, infrastruktur kecerdasan artificial di bidang prioritas, dan kode etik (BPPT, 2020)

Dengan melalui kebijakan lunak industri (soft industrial policy) maka pemerintah bisa mendorong organisasi sektoral (misalnya asosiasi perusahaan yang jadi kunci untuk mengambil manfaat dari Industri 4.0 seperti system engineering, system integrator) untuk berperan. Jika organisasi semacam itu lemah, maka perlu diberikan dukungan kepada sektor untuk meningkatkan perannya, atau membentuknya jika belum ada. Karena itulah kolaborasi pemerintahswasta sangatlah penting. Untuk itu harus disiapkan mekanisme dan struktur yang memfasilitasi pengguna untuk bisa salingterhubung, menyuarakan, berinovasi, berbagi, memilih dan saling percaya/trust dengan cara yang mendorong inovasi namun tetap menghargai nilai penting lain- seperti hak pengguna.

Dari sisi teknis perlu disiapkan enabling technologies yang pemanfaataannya bisa terjangkau oleh berbagai pelaku digital ekonomi lintas sektoral agar memicu inovasi kreatif. (Hadi \& Murti, 2019). Untuk dapat menjalankan kebijakan tersebut maka kehadiran peran pemerintah adalah mutlak. Dalam arti, tidak semuanya harus dilakukan sendiri, karena memang tidak ada yang mampu untuk itu, namun lebih dalam hal pengorkestrasian proses untuk melancarkan inisiatif yang melibatkan multistakeholder. Tantangan berat dan baru bagi Indonesia, namun tak ada pilihan lain dalam dunia di mana integrasi digital, melalui inisiatif transformasi apapun, telah menjadi kebutuhan dasar.

Sebagai contoh, di Kemenperin telah menginisiasi percepatan transformasi industri 4.0 dengan membentuk ekosistem industri 4.0 yang disebut Ekosistem Indonesia 4.0 (SINDI 4.0) sebagai framework yang dapat bersinergi dan berkolaborasi, antara pemerintah, perusahaan kawasan, pelaku industri, akademisi dan lembaga litbang, technical provider, konsultan dan pelaku keuangan (Kemenperin, 2020).

Dalam SINDI 4.0, terdapat tools penilaian Indonesia Industry 4.0 Readiness Index (INDI 4.0) untuk mengetahui posisi kesiapan industri bertransformasi industri 4.0 di era new normal ini, upaya yang dilakukan Kemenperin mempercepat transformasi industri 4.0 yaitu meningkatkan kesadaran (awareness) agar industri tetap produktif di masa pandemi dengan dukungan implementasi teknologi industri 4.0 sekaligus tetap patuh memenuhi protokol kesehatan.

Sejalan dengan implementasi industri 4.0 untuk dapat menyiasati adaptasi kebiasaan baru di masa pandemi Covid-19, Kemenperin mengembangkan panduan program Learning Factory Industri 4.0 dan di dalamnya terdapat tools assessment 
Technoware, Infoware,

Humanware, Orgaware (THIO). Learning Factory Industri 4.0 merupakan sebuah platform kelanjutan dari INDI 4.0 yang memuat metode penerapan industri 4.0 bagi perusahaan manufaktur di tanah air. Untuk Assesment THIO ini fungsinya untuk melihat sejauh mana kondisi kesiapan fasilitas fisik industri (Technoware), kesiapan sumber daya manusia (Humanware), ketersediaan data dan sistem informasi (Infoware) dan kesiapan manajemen organisasi (Orgaware) yang dimiliki (Utomo \& Setiastuti, 2019).

Adapun kunci keberhasilan pelaksanaan industri 4.0 terletak pada kualitas SDM dan kesiamapan infrastruktur digital. Dengan demikian, keberhasilan program dari Learning Factory Industri 4.0 tidak hanya diukur dari sisi ekonomi, akan tetapi harus diukur juga dari keuntungan intangible, seperti jumlah industri yang menerapkan industri 4.0, alokasi ketersediaan SDM yang melakukan program peningkatan ketrampilan (up skilling) atau pembaharuan ketrampilan (reskilling) terkait kebutuhan industri 4.0, pengembangan keunggulan teknologi tepat guna yang lebih kompetitif, pengembangan kreatifitas berbasis pada Hak Kekayaan Intelektual (HKI) khususnya paten produk industri yang dihasilkan.

Selain itu, juga melihat sejauh mana kondisi kesiapan teknologi, kemampuan SDM, ketersediaan data dan sistem informasi serta struktur manajemen organisasi yang dimiliki. Identifikasi kendala dan poin point yang dihadapi merupakan hal penting yang perlu menjadi perhatian sebagai langkah dan arah strategis serta selanjutnya menjadi landasan rekomendasi untuk membuat demonstrasi dalam pemanfaatan teknologi industri 4.0, salah satunya adalah ketersediaan jaringan koneksi dan fasilitas digital yang mendukung (Kemenperin, 2020).

\section{Kesimpulan}

Platform Ekosistem menjadi media untuk dapat membangun sinergi serta kolaboratif lintas industri dengan seluruh stakeholder dalam upaya mempercepat transformasi industri 4.0 sesuai program prioritas nasional Making Indonesia 4.0. Sejalan dengan itu, dilakukan koordinasi antar pihak dalam proses tansformasi industri 4.0, serta membangun jejaring untuk mengembangkan kerjasama yang positif baik pemerintah, akademisi atau R\&D, pelaku / asosiasi industri, technical provider, konsultan dan tentunya financial actor dalam akselerasi proses transformasi industri 4.0. Hal tersebut menambah wawasan yang terus berkembang untuk mendapatkan model Platform ideal sekaligus terbaik sebagai wadah kolaborasi multistakeholder bagi transformasi digital guna membangun ekosistem inovasi Industri 4.0 digunakan dan sesuai karakterisik dan kebutuhan Industri di Indonesia.

Tata kelola platform industri 4.0 ini diharapkan dapat menjadi masukan penting sebagai rekomendasi dalam merumuskan strategi dan kebijakan nasional sebagai upaya percepatan implementasi industri 4.0 dalam mempersiapkan infrastruktur yang dibutuhkan oleh pelaku industri khususnya industri manufaktur prioritas dapat bertransformasi ke arah industri 4.0. Karena belum adanya peraturan perundangan terkait pengembangan Industri 4.0 secara formal sebagai acuan implementasi, saat ini banyak industri masih kesulitan untuk mencari acuan implementasi pengembangan Industri 4.0.

Adanya dukungan berupa model platform pengembangan industri 4.0 yang tersistematis dan terintegrasi dengan baik dalam satu kesatuan ekosistem maka diharapkan akan terciptanya kolaborasi antar pemangku kepentingan sehingga dapat tersusun standard/platform teknis bersama untuk terciptanya pasar dalam negeri yang berdaya saing dan mandiri.

\section{Referensi}

BPPT. (2020). Bangun Ekosistem Industri 4.0, BPPT rangkul Industri dan Tekankan Peran Audit Teknologi. Retrieved from www.bppt.go.id: https://www.bppt.go.id/siaran-pers/4071-sp047-x-2020-bangun-ekosistem-industri-4-0bppt-rangkul-industri-dan-tekankan-peranaudit-teknologi

Faisal, F., \& Syam, H. (2020). A Key competencies in the industrial age 4.0. Indonesian Journal of Fundamental Sciences, Vol 6, No.1, 47-52.

Hadi, S., \& Murti, H. W. (2019). Kajian Industri 4.0 untuk penerapannya di Indonesia. Jurnal Manajemen Industri dan Logistik, Vol. 3, No.1, 1-13.

Irianto D. (2017). Industri 4.0 : The Challenges of Tomorrow. Disampaikan pada Seminar Nasional Teknik Industri, Malang.

Jay, L., Bagheri, E., \& Kao, H. (2013). Recent advances and trends in predictive manufacturing systems in big data environment. Manufacture Letter, Vol.1, No.1.

Kagermann H, Wahlster W, \& Helbig J. (2013). Recommendations for Implementing the Strategic Initiative industries 4.0. Industries 4.0 Working Group, Germany. 
Kemenperin. (2020). Siaran Pers : Penerapan Industri 4.0 Gairahkan Sektor manufaktur hadapi Era New Normal. Retrieved from www.kemenperin.go.id: https://kemenperin.go.id/artikel/21807/Penera pan-Industri-4.0-Gairahkan-SektorManufaktur-Hadapi-Era-New-Normal

Kohler, D., \& Weisz, J. (2016). Industry 4.0: the challenges of the transforming manufacturing. Germany:BPIFrance.

Utomo, S., \& Setiastuti, N. (2019). Penerapan metode Technometrik untuk penilaian kapabilitas teknologi industri galangan kapal dalam menyongsong era industri 4.0. Jurnal Sains Komputer dan Informatika, Vol.3, No.1, 100114.

Utomo, S., Susalit, Setiastuti, N., \& Hakim, A. R. (2020). Innovation 4.0: Penilaian Tingkat Kesiapan Inovasi Perguruan Tinggi XYZ Menghadapi Revolusi Industri 4.0. Infotekjar, Vol 4, No.2, 118-123.

Veile, J. W., \& Kiel, D. (2019). Lessons learned from Industry 4.0 implementation in the German manufacturing. Journal of Manufacturing Technology Management, Vol 31.No.5, 977997.

Yuliati, Y., \& Suhandi, D. (2019). Pembelajaran Sains di Era Revolusi Industri 4.0. Jurnal cakrawala Pendas, Vol.5, No.2( ), 167-171. 